\title{
Terrorist Attacks \& Presidential Approval Rating
}

Elizabeth BENNETT' ${ }^{15}$, New York University

\begin{abstract}
1

fter the attacks of September $11^{\text {th }}$ the U.S. focused much of its foreign policy efforts on the War on Terror and prevention of another attack on U.S. soil. This paper will look at terrorist attacks dating back to 1970 in order to fully understand the impact of terrorist attacks on U.S. presidential approval ratings and the existence of the 'rally around the flag' effect during different administrations. Location, lethality, style, and political affiliation of the president will be variables focused on in a pre and post 9/11 context. This paper will give special consideration to 9/11, excluding the attacks in many cases, in order to view if there is a significant stable impact on approval ratings from terrorist attacks over time.
\end{abstract}

${ }^{15}$ Elizabeth Bennett, 22, Albany NY, is a graduate student at New York University pursuing an M.A. in International Relations/International Security. In 2013 she received her Bachelor of Science degree in Managerial Economics from Bentley University. Her interests include security studies, terrorism, and South Asia/Middle East affairs. 


\section{$\mathrm{P}$} Introduction

resident George W. Bush's first term in office was met with an alltime high presidential approval rating of 90 percent. This spike in approval ratings after the attacks of September $11^{\text {th }}$ is attributed to the nation uniting under the president for support and leadership, an effect know as the 'rally around the flag' effect, previously applied to international crisis and is now viewed with terrorist attacks. This study looks at this type and similar effects on how terrorist attacks are a determinate of United States presidential approval. Attacks both domestic and abroad will be used at that were against U.S. citizens and U.S. interests. Although the statistics have few domestic attacks included, tactics and strategies used by terrorist organizations are evolving, keeping relevant the real and perceived threat of large-scale domestic attack.

Presidential approval rating fluctuations are attributed to many inputs, economic and otherwise. If terrorist attacks do have a significant effect on approval rating then the characteristics of the attack will be analyzed as well. As mentioned there has been a domestic terrorist attack in just more than one percent of all months from 1970 to 2010, so it is this infrequent type of attack that tends to result in a large rally round the flag effect. For a presidential administration the goal of limited U.S. deaths in these attacks have been successful, with only three attacks with more than 100 Americans died. But depending on the type of lethal attack used by the group could determine the outcome of the impact. To view the impact of these effects, this paper will look at 1) the number of attacks per month, 2) the location of the attack being domestic or in the Middle East, 3) the number of U.S. citizens killed in different attack types such as bargaining (hijacking, skyjacking, and kidnapping), bombings and infrastructure attacks, 4) the impact of being a Republican president when there is a lethal attack, and 5) the impact of being a
Republican president during a domestic attack.

Terrorist methods, tactics, and targets have and continue to evolve but the impact of these attacks on approval ratings is predicted to show stability over a considerable amount of time. As the fight against terrorism wages on presidential approval ratings remain susceptible to attacks and public perception of the handling of an attack. And although terrorist attacks are only one of many variables in approval ratings, attacks from pre and post 9/11 remain a significant variable.

\section{Literature Review}

Since the attacks of September $11^{\text {th }}$ $(9 / 11)$ several studies have explored the relationship between terrorist attacks and the presidential approval rating. Controlling for the economy, scandals, and war, Guilmartin (2004) analyzes presidential approval ratings from 1942-2002 concluding there is a significant relationship between the incidence of terrorist attacks and the approval rating. This study showed that after a lethal terrorist attack Republican presidents experience an increase in approval rating relative to Democrat presidents as well as a relative increase for a Republican presidents when attacks are kidnappings, hostages, and hijackings involving American citizens. And lastly Guilmartin finds that terrorist attacks in the Middle East are positively related to approval in the month following the attack.

There have been additional studies on the 'rally-round-the-flag' effect dating back to President Carter up to the most recent administrations. The 'rally round the flag' effect introduced by Mueller (1973) has three main aspects: an international event that sparks crisis, the event must involve president directly, and the event must be sharp, focused and dramatic. Brody (1984) further explains that the phenomenon 
results from an international crisis where the country is united around the president, stating the effect will only last as long as the crisis. Callaghan and Virtanen (1993) cite the great increase in Carters presidential approval rating at the onset of the Iranian hostage crisis, thus showing the bipartisan impact and susceptibility of all political groups to this effect. In this case independents increased their approval of Carter by 27 percentage points and Republicans and Democrats by 10 and 14 percentage points respectively. Further studies by Hetherington and Nelson (2003) compared presidential approval to three major terror attacks, showing President George W. Bush's presidential approval rating that increased from 57 percent to 90 percent after the attacks of 9/11.

A study differing from most in its field by Johnasen (2008) uses an increase in the level of terror alert to view the impact on presidential approval. Controlling for war, campaigning, and the state of the economy the hypothesis states: when there is a change in the terror alert level, presidential approval increases. In this study the hypothesized relationship between approval ratings and the level of the terror alert (Johnasen). Using the data and results, Johnasen concludes the relationship between the increase of 33 percentage points in presidential approval for George W. Bush is not directly from the rally round the flag effect yet more from a public evaluation of the president's handling of the crisis and resulting foreign policy. Shambaugh (2004) using Gallup Poll data from 1980-2003, demonstrates that the "best predictor of presidential approval following an attack is the level of presidential approval before the attack". Acknowledging the change in approval ratings may be from a lack of public awareness and with increased salience of terrorism after an attack it is expected to have a larger impact on presidential approval, in particular when the human and material cost of terrorism is high.
While the sheer incident of a terrorist attack can directly impact approval rating, many studies test the type of terrorist attack to show level of significance on presidential approval. Using data from Terrorism in the $20^{\text {th }}$ Century, Guilmartin breaks down attacks into categories: was the attack domestic or was it against U.S. citizens abroad, if the attack was foreign, was it in the Middle East, how many people were killed, and what tactics were used- bombing, kidnapping, assassination, skyjacking/hijacking, or hostage taking, and how many attacks occurred between polling periods. Guilmartin's results show by breaking down the type of terrorist attack that every person killed in a terror related "hostage, skyjacking, hijacking, or kidnapping situation, there is a predicted increase of .06 points approval" whereas bombings resulted in a negative correlation with presidential approval.

James and Rioux (1998) add in a variable for the use of force after a terror attack on presidential approval. This variable is used along with time, economy, crisis level, region of attack, U.S. response, U.S.S.R. activity in attack, and causalities. The use of force is measured in ranges of: no use of force, minor use of force, one major force component or strategic nuclear unit, or two or three major force components are used, plus at least one strategic nuclear unit. This study finds the positive impact of rally effect resulting from a terrorist attack is sensitive to the resulting use of force and depending on the level applied the resulting costs could outweigh or negative the initial approval increase. Further James and Rioux show that with a use of force the members of the presidents opposing party will show the greatest decrease in support.

Studies on determinants of presidential approval use both economic and noneconomic indicators to analyze impacts of each. Fox \& Phillips use real GDP growth, target unemployment, and inflation to view the importance of economic 
conditions to people when determining presidential approval. Winder (2002) also uses unemployment and inflation rate, as well as the honeymoon effect in a regression of presidential approval. This study by Winder breaks down the importance of economic variables concluding although both coefficients for unemployment and inflation were negative, economic variables more significant to males than females in their approval of the president. Both Fox and Phillips and Berlemann and Enkelmann include variables for scandal and war, where scandal is included that represents the negative public personal and political incidents, such as Watergate and the IranContra scandal, to control for shift in popularity due to these events. These studies factor in the impact of terror attacks retain focus on economic determinants and from that which economic determinant is most influential for the political party of the president (Berlemann and Enkelmann).

This study will use similar framework as prior studies to control for variables of: honeymoon, war, scandal, and unemployment. Using the rally round the flag effect as basic framework for time series analysis beginning at 1970 terrorist attack characteristics will be used to analyze the various types and degree of the effects. Location is an important variable in terrorist attacks and approval ratings, like similar studies a dummy variable for domestic attacks will but used, as well a variable for terrorist attacks in the Middle East. Other variables such as attack lethality and attack type will be used in a similar manner to prior studies. All of these terrorist attack variables will largely determine if a rally effect takes place and if so the scale and duration of the effect.

\section{Theoretical Model}

Much presidential literature shows the strong correlation between economic indicators such as unemployment and approval ratings. Concluding a negative correlation as unemployment goes up presidential approval goes down. Similarly, there is a strong positive correlation between GDP growth rates and approval rating. A non-economic indicator such as scandal is unanimously believed to have a negative effect on approval rating. But in other factors such as domestic and international crisis have more variation in their outcomes.

John Mueller (1973) first introduced the rally around the flag effect. This theory includes three aspects: event is an international event that triggers crisis, second that the event must involve the president directly, and third that event must be dramatic and focused. This effect, when all three aspects are met, can greatly increase presidential approval. This theory states it is a natural reaction and a symbol of unity to support the president in the time of crisis regardless of politics or policies. The duration of this effect is believed to be only a few months, regardless of the outcome of the crisis. It was Hetherington and Nelson (2003) that first applied this rally round the flag effect to the attacks 9/11 increasing the scope of this effect to domestic crisis. This effect is clearly visible after the attacks of 9/11 with the spike in President George W. Bush approval ratings, figure 1. At this point once the 'rally round the flag' effect was applied to domestic events such as 9/11, various characteristics were introduced in order to further analyze the degree of impact from a domestic terrorist attack. Major variables include the location of the attack, the lethality of the attack, and political party of the president at the time of the attack.

Five different OLS models will be used in order to test the impact of these factors on the rally round the flag effect. In around 44 percent of the months in dataset there has been no incident of terrorist attacks (figure 2) and almost 99 percent of the months there were no attacks on domestic soil (figure 3). Attacks in the Middle East occurred more frequently with 24 percent of the months experiencing an attack in the Middle East (figure 4). The lethality of all of the terrorist attacks has been minimal since 1970 in this dataset there 
is only two recorded attacks with 100 or more U.S. citizens killed, once of which being $9 / 11$. Since this variable is measured in one U.S. citizen killed it will still remain an important factor in approval ratings.

With over 400 months (figure 5) with no attack or an attack resulting in no U.S. lives lost, it is predicted that a high profile attack like a hijacking will result in a positive impact on approval ratings. For the most part, Americans have been free of terrorist attacks at home and abroad. But when attacks do occur it is likely that Americans look to the president for unity and support until the situation has been resolved or diffused.

\section{Data and Variables}

The dependent variable for this study is national presidential approval rating on a monthly basis from 1970-2010 that results in 491 observations for this data set. Data for this variable was collected from Gallup, where the polling question asks people if they approve or disapprove of how the president is handling his job. Statistics on this variable and all independent variables can be found in table 1 .

Data for the independent varaibles on terrorists attacks comes from the Global Terrorism Databse. Here only attacks were used if the target was a U.S. citizen or if the attack was against U.S. interests, including ships, buildings, etc., regardless of the location or magnitude of the attack. These terrorist attacks are additionally sorted by attacks perpetrated by a group of 53 foreign non-state organizations identified by the Department of State as posing the greatest threats to U.S. citizens. The independent variable, terrorist attack, is a dummy variable that will have a 1 if an attack occurred in that month and a 0 if no attack occurred. The lagged incidence of terrorist attacks will show the delayed influence, measured if an attack happened in the previous month. The variable num_month is the number of terrorist attacks per month that will be measured by the frequency of attacks in said month and in the prior month for the lagged variable num_month $\mathrm{t}_{\mathrm{t}-1}$.

\section{Terrorist Attack Variables}

To analyze the impact of the varying types of lethal of attacks on presidential approval the following variables are used: number of U.S. killed (nkilledUS), number of U.S. killed in bombing attack (nkilledUSbomb), number of U.S. killed in infrastructure attack (nkilledUSinfra), and number of U.S. killed in bargaining attack (nkilledbar). The number of U.S. killed is a measure of how many U.S. citizens were killed in a month with an attack. To separate by attack type, the number of U.S. killed in a bombing attack is measured in number of U.S. citizens killed in a bombing type attack in that month. Number of U.S. killed in bargaining attack and infrastructure attack are similar variables to number U.S. killed in bombing but the type of attack is changed to view effect.

The variables analyzing the location of the attack have been coded into two dummy variables: domestic and Middle East. Domestic is given a 1 if attack occurred in the United States and a 0 if attack occurred anywhere else. Middle East is given a 1 if the attack occurred in the Middle East and a 0 if attack occurred anywhere else. An interaction term of GOP_nkilledUS is used to view the impact of the number of U.S. citizens killed in an attack if the president was a Republican, relative to a Democrat president. And lastly GOP_Domestic was coded to look at the impact on ratings during a Republican presidency if there was a domestic attack relative to the impact if the president was a Democrat. This data viewed on a monthly basis is from the Global Terrorism Database and descriptive statistics for this data can be found in table 1 .

Economic and Other V ariables 
Presidential approval ratings are susceptible to the state of the economy, war, and scandal during the time in office. To control for the amount of time the president has been in office the log of time is used, which is measured by number of days the president has been in office. And the honeymoon variable is created to control for the honeymoon effect a president enjoys the first seven months of his administration, here a 1 is entered for the first seven months of each president's term and a 0 for all of the other months outside of the honeymoon time frame. Due to the influence the economic conditions have on presidential approval rating each month, the variable of lagged unemployed is used to control for the effect of changing economic conditions during a presidency. This national monthly data was obtained from the St. Louis Fed and is measured in percentage points.

A control for the attacks of $9 / 11$ was created due to the outlying nature of the attack and great effect on presidential approval rating. Here a 1 is entered during the first four months after $9 / 11$ and a 0 for all other times. The next variable is a dummy for GOP that is a measure of the president's political party, if Republican will be coded as a one 1 and all other political affiliation is given a 0 . Finally to control for personal and administration scandal, the dummy for scandal variable is included. During the times of Watergate 04/197307/1974, Iran-Contra 12/1986-12/1988, and the Lewinsky scandal 01/1998-08/1998 a 1 was entered and all other times a 0 was assigned. Data on scandals is sourced from "Presidential Scandals and Job Approval". Descriptive statistics for this data is found in table 1.

\section{Empirical Methodology}

With approval ratings influenced by both economic and noneconomic indicators in order to view the effects of all of the variables five OLS regression models were run under: number of attacks per month, location of attack, lethality and type of attack, lethality of attack when president was Republican, and impact of a domestic attack when a Republican is president. If the first model results in a significant impact on presidential approval ratings, the subsequent models will provide clarity on significant attack characteristics and their impact.

The following OLS regression models use the same dependent variable: presidential approval rating on a monthly basis from 1970-2010. In order to test if the occurrence of a terrorist attack is significant on presidential approval ratings the following model was used:

$$
\begin{aligned}
& B_{4}\left(\text { wartime }_{t-1}\right)+B_{5}\left(\text { unemployment }_{t-1}\right)+ \\
& B_{6} \text { (scandal) } \quad+B_{7} \text { (Indicator_911) } \\
& +B_{8} \text { (monthdummy2) } \\
& \left.+\ldots B_{18} \text { (monthdummy }{ }_{12}\right)+B_{19} \text { (yeardumm } \\
& \left.y_{2}\right)+\ldots B_{58}\left(\text { yeardummy }_{41}\right)
\end{aligned}
$$$$
\text { (1) } B_{2} \text { (lntime) }+B_{3} \text { (honeymoon) }+
$$

It is expect when there is a terrorist attack in the prior month it will result in a positive effect on PAR $\left(B_{1}>0\right)$. This conclusion is drawn from the rally effect theory a president experiences after a terrorist attack. All of the models include: the log of days in office (lntime), honeymoon, unemployment, scandal, wartime, a 9/11 indicator, and month and year dummies. Both controlling for time president has been in office honeymoon is expected to be positive $\left(\mathrm{B}_{3}>0\right)$ while the log of time is expected to be negative $\left(B_{2}<0\right)$. Scandal is included due to the public nature of these adverse events and it is expected to have a negative impact on popularity for the presidential administration $\left(\mathrm{B}_{6}<0\right)$. The wartime dummy variable because presidential approval prone to public perception of the war is anticipated to result in a negative coefficient $\left(B_{4}<0\right)$. The lagged unemployment percentage is included in all of the models due to the inverse relationship between increasing unemployment and presidential approval $\left(\mathrm{B}_{5}<0\right)$ (Fox and Phillips).

Again because the attacks of $9 / 11$ are a considerable outlier in, a variation of this 
first model will be run to test if effect of a terrorist attack has been stable over a long period of time or if it has become significant in the decade since 9/11. To do this all of the dependent and independent variables remain the same, but the time frame of the model is shortened 1970-2000, in order to exclude $9 / 11$.

$$
\begin{aligned}
& \left.P A R=B_{0}+B_{1} \text { (num_month }_{t-1}\right)+ \\
& \text { (1a } B_{2} \text { (lntime) }+B_{3} \text { (boneymoon) }+ \\
& B_{4}\left(\text { wartime }_{t-1}\right)+B_{5}\left(\text { unemployment }_{t-1}\right)+ \\
& \left.B_{6}(\text { scandal })+B_{8} \text { (monthdummy } 2\right)+ \\
& \text {... } \left.B_{18} \text { (monthdummy } y_{12}\right) \\
& +B_{19}(\text { yeardummy } 2)+\ldots B_{58} \text { (yeardummy } 32 \\
& \text { ) }
\end{aligned}
$$

The mean for attacks per month prior to $9 / 11$ is equal to 1.33 which is slightly higher than the mean post $9 / 11$ of .718 so it is predicted that the coefficient will be significant and very similar to the coefficient in the first attack. This result should exhibit that although the post 9/11 world has increased notice on counterterrorism and terrorist attacks the effect of an attack on approval ratings has been consistent over a considerable amount of time.

To analyze the effect of location of a terrorist attack two dummy variables were coded, domestic and Middle East, to regress against presidential approval. Both the current and lagged month a used in the model along with all of the economic and time control variables from the prior regressions. The location model is as follows:

$$
\begin{aligned}
& \left.\left.P A R=B_{0}+B_{1} \text { (lntime }\right)+B_{2} \text { (boneymoon }\right)+ \\
& \left.\left.B_{3} \text { (mideast }\right)+B_{4}\left(\text { mideast } t_{-6}\right)+B_{5} \text { (domestic }\right)+ \\
& B_{6}\left(\text { domestic }_{t-6}\right)+B_{7}\left(\text { unemployment } t_{-1}\right)+ \\
& B_{8}\left(\text { wartime }_{t-1}\right)+B_{9}(\text { scandal })+ \\
& B_{10} \text { (Indicator_911) }+B_{11} \text { (monthdummy2) } \\
& +\ldots B_{21}\left(\text { monthdummy } y_{12}\right)+B_{22}\left(\text { yeardummy }_{2}\right) \\
& +\ldots B_{61}\left(\text { yeardummy } y_{41}\right)
\end{aligned}
$$

For this model it was projected that an attack that occurred in the Middle East would result in a negative coefficient $\left(\mathrm{B}_{3-}\right.$ $\left.{ }_{4}<0\right)$ for both the current and lagged months. The negative coefficient for Middle
East lagged six months (MidEast ${ }_{t-6}$ ) is predicted to show the degree in which the public approves the president's handling of the attack in the long term. But if the attack was domestic then the coefficient for this dummy variable is expected to be positive $\left(B_{5-6}>0\right)$, resulting in a rally around the flag effect for the current president.

Since most terrorist attacks are unique these characteristics will have a varying effect on presidential approval rating. The lethality of an attack (nkilledUS) is a variable which impact depends on the total U.S. citizens killed and the style of attack used by perpetrators. The following model was used to differentiate number of deaths and deaths resulting from a specific attack type.

$$
\begin{aligned}
& P A R=B_{0}+B_{1} \text { (lntime) }+B_{2} \text { (honeymoon) } \\
& \left.+B_{3} \text { (nkilledUS } S_{t-1}\right) \quad+B_{4}\left(n k i l l e d U S_{t-2}\right) \\
& \left.\left.+B_{5} \text { (nkilledbar }{ }_{t-1}\right)+B_{6} \text { (nkilledbar } r_{t-2}\right) \\
& \left.+B_{7} \text { (nkilledbomb } t_{-1}\right)+B_{8} \text { (nkilledbomb } \\
& \left.{ }_{2}\right)+\quad B_{9}(\text { nkilledinfrat }-1)+ \\
& \left.\left.B_{10} \text { (nkilledinfra }_{t-2}\right) \quad+B_{11} \text { (wartime }_{t-1}\right)+ \\
& \left.B_{12} \text { unemployment } t-1\right)+B_{13} \text { (scandal) } \\
& +B_{14} \text { (Indicator_911) } \\
& +B_{15}(\text { monthdummy } 2) \\
& \left.+\ldots B_{25} \text { (monthdummy } 12\right) \\
& +B_{26}(\text { yeardummy })+\ldots B_{64}(\text { yeardummy } 41 \\
& \text { ) }
\end{aligned}
$$

When breaking the characteristics of an attack down it is expected the coefficient for number of U.S. citizens killed lagged one month will be negative $\left(B_{3}<0\right)$, showing an inverse relationship with increasing number of U.S. deaths and approval. Also the same negative sign is expected for number killed in a bombing $\left(\mathrm{B}_{7}<0\right)$ and number killed in an infrastructure $\left(\mathrm{B}_{9}<0\right)$ attack lagged one month. For the number of U.S. citizens killed in bargaining attack (hijacking, skyjacking, kidnapping), due to the increase in media coverage, it is predicted that the coefficient for this variable would be positive $\left(B_{5}>0\right)$, resulting in a rally around the flag effect.

For the next model the political party of the president is coded as a dummy variable with a 1 for Republican and 0 for a 
Democrat. An interaction term, GOP_nkilledUS was created to analyze the effect of a lethal terrorist attack for a Republican president relative to a Democrat. This variable is lagged for one and two months (GOP_nkilledUS ${ }_{\mathrm{t}-1,}$ GOP_nkilledUS $S_{t-2}$. The following OLS model was used:

$$
\begin{aligned}
& P A R=\quad B_{0}+ \\
& \text { (4) } \left.B_{1} \text { (lntime }\right)+B_{2} \text { (boneymoon) }+ \\
& B_{3}(G O P)+\quad B_{4}(\text { nkilledUS })+ \\
& B_{5}\left(\text { gop_nkilled } U S_{t-1}\right)+ \\
& B_{6}\left(\text { gop_nkilled } U S_{t-2}\right)+B_{7} \text { (wartime } \\
& \text { 1) }+B_{7}\left(\text { unemployment } t_{t-1}\right)+B_{9}(\text { scandal })+ \\
& B_{10} \text { (Indicator_911) } \\
& +B_{11} \text { (monthdummy2) } \\
& +\ldots B_{21}\left(\text { monthdummy }_{12}\right) \\
& +B_{22}\left(\text { yeardummy }_{2}\right) \\
& +\ldots B_{61}(\text { yeardummy } 41 \text { ) }
\end{aligned}
$$

For this model, it is predicted that if the president is a Republican a terrorist attack will have a larger positive impact on approval ratings than if president was a Democrat. Although this effect is projected to be small, it is significant in recalling that number of U.S. killed is measured per individual victim of the attack.

Following the same method as model (4) here models (5) and (5a) look at the impact on a Republican president if there was a domestic attack, relative to if president was a Democrat. The following OLS model was used:

$$
\begin{aligned}
& P A R=B_{0}+B_{1}(\text { Intime })+B_{2}(\text { honeymoon })+ \\
& B_{3}(G O P)+\quad B_{4} \text { (Domestic)+ } \\
& B_{5}\left(G O P \_D o m e s t i c\right)+B_{6} \text { (unemployment } \\
& \text { 1) } \left.+B_{7} \text { (wartime }{ }_{-1}\right)+B_{8}(\text { scandal })+ \\
& B_{9}\left(\text { Indicator_911) }+B_{10}\right. \text { (monthdummy2) } \\
& \left.+\ldots B_{20} \text { (monthdummy }{ }_{12}\right) \\
& +B_{21}\left(\text { yeardummy }_{2}\right)+\ldots B_{60}\left(\text { yeardummy }_{41}\right)
\end{aligned}
$$

For this model it is predicted that a Republican president would receive great positive effect from a domestic attack than a non-Republican president, resulting in a positive coefficient $\left(B_{5}>0\right)$. Just as in model (4) the effect of this interaction term will be small.
Because the rally around the flag effect for President Bush was so great from the $9 / 11$ attacks to test the stability of the coefficient in model (5), this model excludes 9/11 looking at the dataset from 1970-2000 on a monthly basis. The following OLS model, (5a), was used:

$$
\begin{aligned}
& P A R=B_{0}+B_{1}(\text { Intime })+B_{2}(\text { honeymoon })+ \\
& \text { (5a) } B_{3}(G O P)+\quad B_{4} \text { (Domestic) }+ \\
& B_{5}\left(G O P \_D o m e s t i c\right)+B_{6}(\text { unemployment } \text {. } \\
& \text { 1) }+B_{7}\left(\text { wartime }_{t-1}\right)+B_{8}(\text { scandal })+ \\
& B_{9} \text { (monthdummy2) } \\
& +\ldots B_{19}\left(\text { monthdummy }_{12}\right) \\
& +B_{2}\left(\text { yeardummy }_{2}\right)+\ldots B_{59}\left(\text { yeardummy }{ }_{32}\right)
\end{aligned}
$$

It is predicted for this model and interaction term GOP_Domestic that the coefficient will be positive $\left(\mathrm{B}_{5}>0\right)$, indicating a higher approval rating for Republicans than nonRepublican presidents following a domestic attack. This coefficient is predicted to be significant but smaller than the same coefficient in model (5).

\section{Findings}

Because this data set is a time series, it is to be expected that presidential approval rating from this month to be related to that of previous months. For all of the models a correction for serial correlation is used.

For model (1), reported in table 2, the results predicted the number of attacks coefficient to be positive and significant at $\alpha=.05$. The positive coefficient of .362 means with an increase of one more attack in the prior month, presidential approval rating will increase by .362 percentage points. Predicted approval rating at the beginning of a president's administration (first twelve months) is 4.65 percentage points higher than after the honeymoon period. Once this time period is over the model predicts a decay in support with the log time of time coefficient -2.66, significant at $\alpha=.01$, suggesting an increase of 100 percent days in office will decrease approval rating 2.66 percent. 
For economic variables, results were as predicted and similar the conclusion of Fox \& Phillips. Unemployment as predicted has a negative significant coefficient of 2.19, meaning with an increase of unemployment by 1 percent, presidential approval ratings decease by 2.19 percentage points, significant at $\alpha=.05$. Scandal was to capture the negative personal events in presidential administrations, the coefficient of -9.73 , significant at $\alpha=.01$, is as predicted. Lastly the control for $9 / 11$ is used due to the magnitude of this event, as theorized with the rally round the flag effect this coefficient did in fact come out positive equal to 20.53 , with significance at $\alpha=.01$.

With an original Durbin Watson statistic of 1.153, indicating a positive correlation, a correction for serial correlation was run on this model resulting in a new Durbin Watson statistic of 2.09. After running this correction the new coefficient remains positive at .0288 but is now not significant at $\alpha=.05$. Number of attacks per month, with lost significant, can still be seen as a preliminary indicator that the incidence of terrorist attacks has some type of an impact on presidential approval ratings.

In order to further conclude terrorist attacks are significant excluding 9/11 this same regression was run but with a limited time frame from 1970-2000. Results from this new model (1a) are in table 2, it is seen in the coefficient for number of attacks per month from the prior month is equal to .383 percentage points and significant with $\alpha=$ .05 , which is very similar to the original coefficient including 9/11. From this coefficient it can be concluded that the structural effect of terrorist attacks on approval ratings has been stable over a long period of time, even though in the post $9 / 11$ world there is an increased importance counterterrorism and the perceived role of the president in preventing attacks.

Location of the attack can be a determinate in the scale of the 'rally round the flag' effect as discussed in prior studies.
Results from model (2) are seen in table 2. The OLS model predicted that a domestic attack would have a larger positive impact on approval ratings then if attack were not on U.S. soil from the current month. The model predicted a negative impact from an attack 6 months prior in the Middle East on approval ratings. This model also included the $\log$ of time, honeymoon, scandal, wartime, 9/11 indicator, and month and year dummies all as controls. This OLS model concluded that a domestic attack will result in an increase of 8.06 percentage points in approval rating, relative to if attack was not domestic, significant at $\alpha=.01$. Similarly this model provided expected results for the Middle East coefficient for an attack 6 months prior equal to -2.01 with significance.

Because of serial correlation and a low original DW statistic of 1.16, again suggesting positive correlation, a correction for this serial correlation was run. After the correction the DW statistic was transformed to 2.07. The coefficient for Domestic remained significant at $\alpha=.05$ with a $p$ value of .016 and a coefficient of 4.48. This result confirms with prior studies by Callaghan and Virtanen the 'rally round the flag' that in this model shows an increase in approval rating of 4.48 percentage points, relative to attack that was not domestic. The coefficient for an attack in the Middle East 6 months prior remained significant for $\alpha=.05$ with a $\mathrm{p}$ value of .012 and maintained the negative impact with a coefficient of -1.37 percentage points. This coefficient shows an attack in the Middle East lagged 6 months is a referendum on the presidents handling of the situation.

It was hypothesized that varying attack styles resulting in U.S. citizens being killed would have different impacts on presidential approval in model (3). When there is an increase in one more U.S. citizen being killed in a bargaining style attack (hijacking, kidnapping, and skyjacking) that is type of attack would be the only one to have a positive result on presidential 
approval. This attack style is high in profile and receives more media attention and public awareness. If the attack was bargaining style, an increase of 1 in the number of U.S. killed in the attack, from two months prior, results in a decrease of -.942 percentage points in approval. For the number of U.S. killed in a bombing the coefficient was -.9089075 . The number of U.S. killed in an infrastructure attack had the largest negative coefficient of -9.98 .

To compare which of the attack types had the largest impact on approval rating standardized betas where computed for all three attack types: bargaining attack= -11.12, bombing attack $=-.829$ and infrastructure attack $=-.053$. Bargaining was predicted to have the largest positive impact out of the three; from these standardized betas for every one standard deviation increase in number of U.S. killed in an attack presidential approval will go down 11.2 standard deviations.

To correction for serial correlation, a new regression was run resulting in a transformed DW statistic from 1.22 to 2.097. The results from this regression again resulted in all negative coefficients: bargaining attack $=-.443$, bombing attack $=$ .405 and infrastructure attack $=-4.52$. For no level significance at $\alpha=.01, .05$, or .1 were the variables significant. Although this model lost significance after the serial correlation correction, the results reveal that no different style attack will yield a positive impact on presidential approval.

Finally in the last models it is seen that political party of the president matters. The interaction term GOP_nkilledUS in an attack in OLS model (4) supports Fiorina and Guilmartin's testing and conclusion that a Republican president will receive more confidence during times on international crisis. For this model the dummy variable for GOP, was significant at $\alpha=.01$ with a coefficient of -18.79 . The next variable, number of U.S. killed in an attack, was significant at $\alpha=.01$ with a coefficient of
.0117. This interaction term with a coefficient of .0066 confirms the positive put small increase of an increase in one U.S. citizen killed in an attack. These OLS results all were significant but positively correlated with a $\mathrm{DW}=1.106$.

To correct for this serial correlation, a new model was run with a transformed $\mathrm{DW}=2.077$. The results for this model were the same as predicted. The coefficient for the interaction term GOP_nkilledUS $\mathrm{t}_{\mathrm{t}-1}$ in an attack, one month lagged was equal to .0066 . With significance at $\alpha=.01$. This model confirms in removing correlation, the theory for Fiorina and Guilmartin's conclusion is again supported for in a terrorist attack under a Republican president an increase U.S. citizen is killed one month prior has an approval rating .006 percentage points higher than a Democrat president.

The next two models analyze the impact of a Republican being in office when a domestic attack occurs. The coefficient of this interaction term GOP_Domestic in model (5), table 2, was equal to 13.61 with significance at $\alpha=.01$. Because of the positive correlation shown in the original $\mathrm{DW}=1.141$, a correction was run transforming the DW statistic into 2.084. The new coefficient for GOP_Domestic is equal to 10.73 significant at $\alpha=.01$. This interaction term shows that if a president is a Republican, a domestic attack will result in approval 10.73 percentage points higher relative to a non-Republican president.

This importance of this term is limited due to the spike in approval Republican President George W. Bush received on 9/11. To view if this impact was stable over a long period of time, the model (5a) was run with data from 19702000, excluding 9/11. The coefficient for GOP_Domestic after a correction for serial correlation was equal to 2.207 , but no longer with significance. After excluding 9/11 from the time frame, the model shows a Republican president when a domestic attack occurs will have an approval rating 
2.207 percentage points higher than nonRepublican presidents. Although this value is insignificant it supports the theory of Fiorina and Guilmartin in Republican presidents receiving higher levels of confidence in international crisis.

\section{Conclusion}

The models demonstrate that although terrorist attacks are not the only determinate for approval ratings, the terrorist attacks remain a significant variable. Terrorist attacks are related to approval rating in the following ways: 1) Domestic attacks in the current month are positively related to presidential approval while attacks in the Middle East from 6 months prior are negatively related and significant. This suggesting the relationship between attacks in the Middle East is judgment on how the president handled the situation. 2) Bargaining type attacks (hijacking, kidnapping, skyjacking) are not positively related to approval ratings regardless of the increased media attention. 3) For Republican presidents that experience a domestic attack or an increase in U.S. deaths in an attack from the prior month receive high approval ratings than that of any other political party.

This analysis supports the rally around the flag effect literature, especially for Republican presidents and those presidents who experienced domestic attacks. From these relationships the impact of a domestic attack and differences in political parties are most significant. We have only seen 6 domestic terrorist attacks since 1970 but combined these attacks have killed over 3,000 people and it will be these domestic attacks from the current month that will have one of the largest effects on approval ratings. The analysis of the impact of a president being a Republican resulted in small but significant results, again confirming Fiorina's theory that Republican presidents historically receive higher confidence during international crisis. When a domestic attack occurs and when there is an increase of lives lost in an attack from prior months Republican presidents are receiving higher approval ratings, relative to Democrat presidents.

Terrorist attacks are only one of many non-economic and economic variables that are determinants of presidential approval. But the above relationships remain consistent and relevant in this type of presidential approval rating analysis. It is only recently, post $9 / 11$, that the rally round the flag effect has been applied to terrorist attacks, domestically and abroad. And while terrorist attacks continue to happen the rally around the flag effect and other effects will continue to play a role in presidential approval ratings.

\section{Works Cited}

Bali, Valentina. "Terror and elections: Lessons from Spain." Electoral

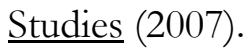

Brody, Richard A. "International Crises: A Rallying Point for the President?" Public Opinion (1984).

Bureau of Counterterrorism. 2012. November 2012

<http://www.state.gov/j/ct/index.h tm>.

Callaghan and Virtanen. "Revised Models of the "Rally Phenomenon": The Case of the Carter Presidency." The Journal of Politics (1993).

Department of Homeland Security. "Fiscal Year 2012 Budget ." 2012. U.S. Department of Homeland Security . November 2012 $<$ http://www.dhs.gov/xlibrary/asse ts/budget-bib-fy2012overview.pdf $>$.

Deptartment of Homeland Security. Preventing Terrorism Results. 2012. December 2012 <http://www.dhs.gov/topic/preven ting-terrorism-results $>$.

Fox, Gerald and Earl Phillips. "Interrelationship between presidential approval, presidential votes and macroeconomic 
performance, 1948-2000." Journal of Macroeconomics (2002).

Gallup. Presidential Approval Ratings. 2012. $<$ http://www.gallup.com/poll/1166 77/presidential-approval-ratingsgallup-historical-statisticstrends.aspx $>$.

Global Terrorism Database. October 2012. Codebook: Inclusion Criteria and Variables. October 2012 <http://www.start.umd.edu/gtd/do wnloads/Codebook.pdf $>$.

Guilmartin, Eugenia. "Terrorist Attacks and Presidential Approval from 19492002." (2004).

Hetherington and Nelson. "Anatomy of a Rally Effect: George W. Bush and the War on Terrorism." Political Science and Politics (2003).

James, Patrick and Sébastien Rioux. "International Crises and Linkage Politics: The Experiences of the United States, 1953-1994." Political Research Quarterly (1998): 781-812.

Johansen, Morgen. "Terror Tactics:The Link between Terror Alerts and Presidential Approval." (2004).

LaFree, Yang and Crenshaw. "Trajectories of Terrorism: Attack Patterns of Foreign Groups That Have Targeted The United States, 1970-2004." Criminology \& Public Policy, Vol. 8 no. 3 (2009): 445-473.

Lebo, Matthew and Daniel Cassino. "The Aggregated Consequences of Motivated Reasoning and the Dynamics of Partisan Presidential Approval." Political Psychology (2007).

Library of Congress. Military History and Military Science: Wars. 2012.
$<$ http://www.loc.gov/rr/main/alco ve9/military/wars.html>.

Lledbetter Iii, Titus. Alabama, Colorado Delegations Go To Bat for United Launch Alliance. 8 October 2012. $<$ http://www.spacenews.com/articl e/alabama-colorado-delegations-gobat-united-launch-alliance>.

P, Fiorina. Morris. "'Electoral Politics in the Wake of 9/11."." American Government in a Changed World. NY: Longman Publishing Group, 2002.

Pellerin, Cherly. Report Urges Lifting Some Satellite Export Controls. 18 April 2012. 2012 <http://www.defense.gov/news/ne wsarticle. aspx?id $=67993>$.

Shambaugh, George. "Public Prudence, the Policy Salience of Terrorism and Presidential Approval following Terrorist Incidents." International Security and Arms ontrol Section of the American Political Science (2004).

St. Louis FED. Civilian Unemployment Rate (UNRATE). 2012.

$<$ http://research.stlouisfed.org/fred 2/series/UNRATE $>$.

Stapley, Criag. "The Domestic Rally Effect and Terrorism." Global Security Studies (2012).

State, U.S. Dept. of. Foreign Terrorist Organizations. September 2012. <http://www.state.gov/j/ct/rls/oth er/des/123085.htm>.

Willer. "HE EFFECTS OF GOVERNMENT-ISSUED TERROR WARNINGS ON PRESIDENTIAL APPROVAL." CURRENT RESEARCH IN SOCIAL PSYCHOLOGY (2004). 


\section{APPENDIX 1}

Figure 1

President George W. Bush's Presidential Approval Rating Jan-01 thru Feb-02

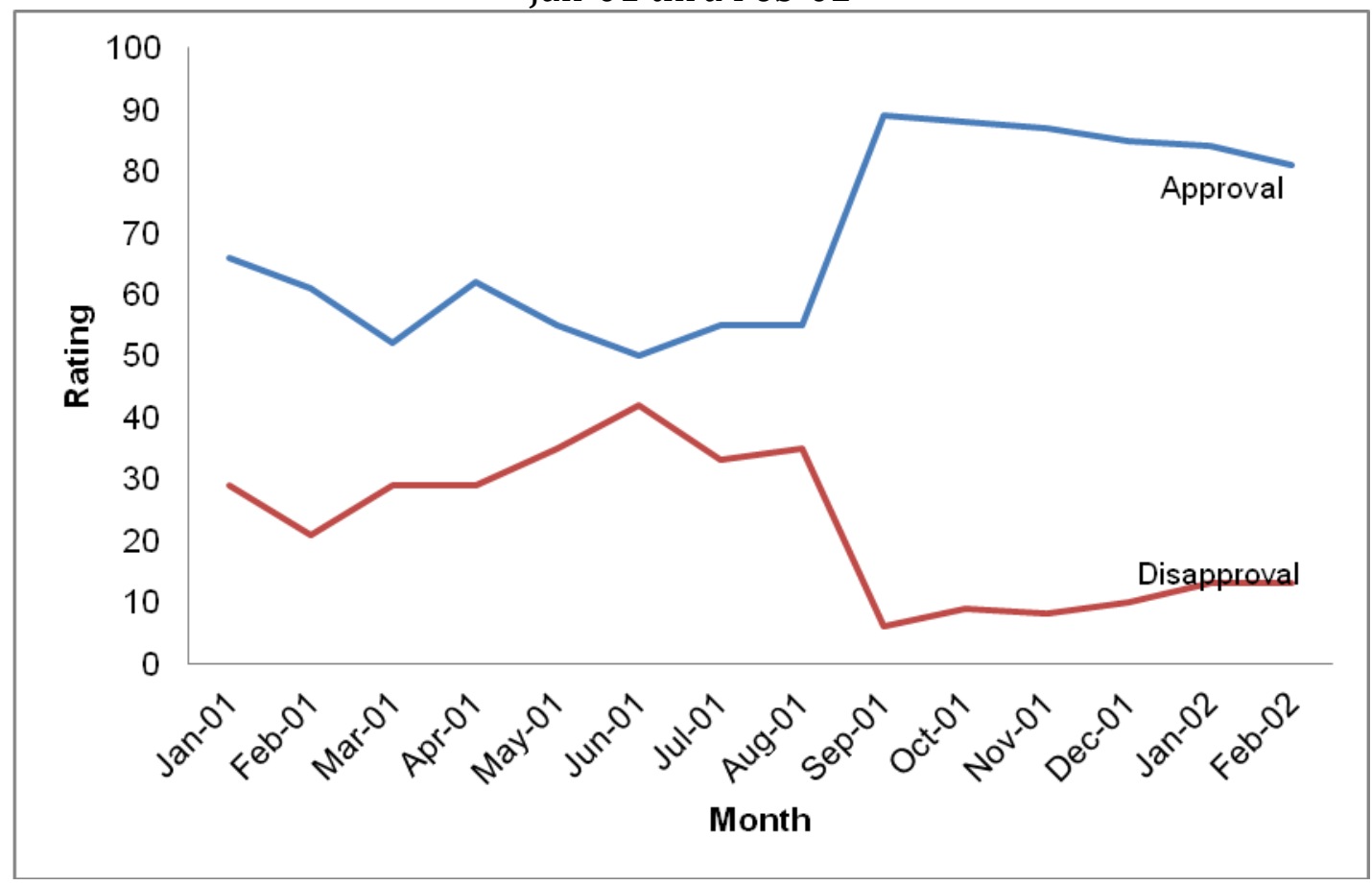

Figure 2

Frequency of Attacks per month

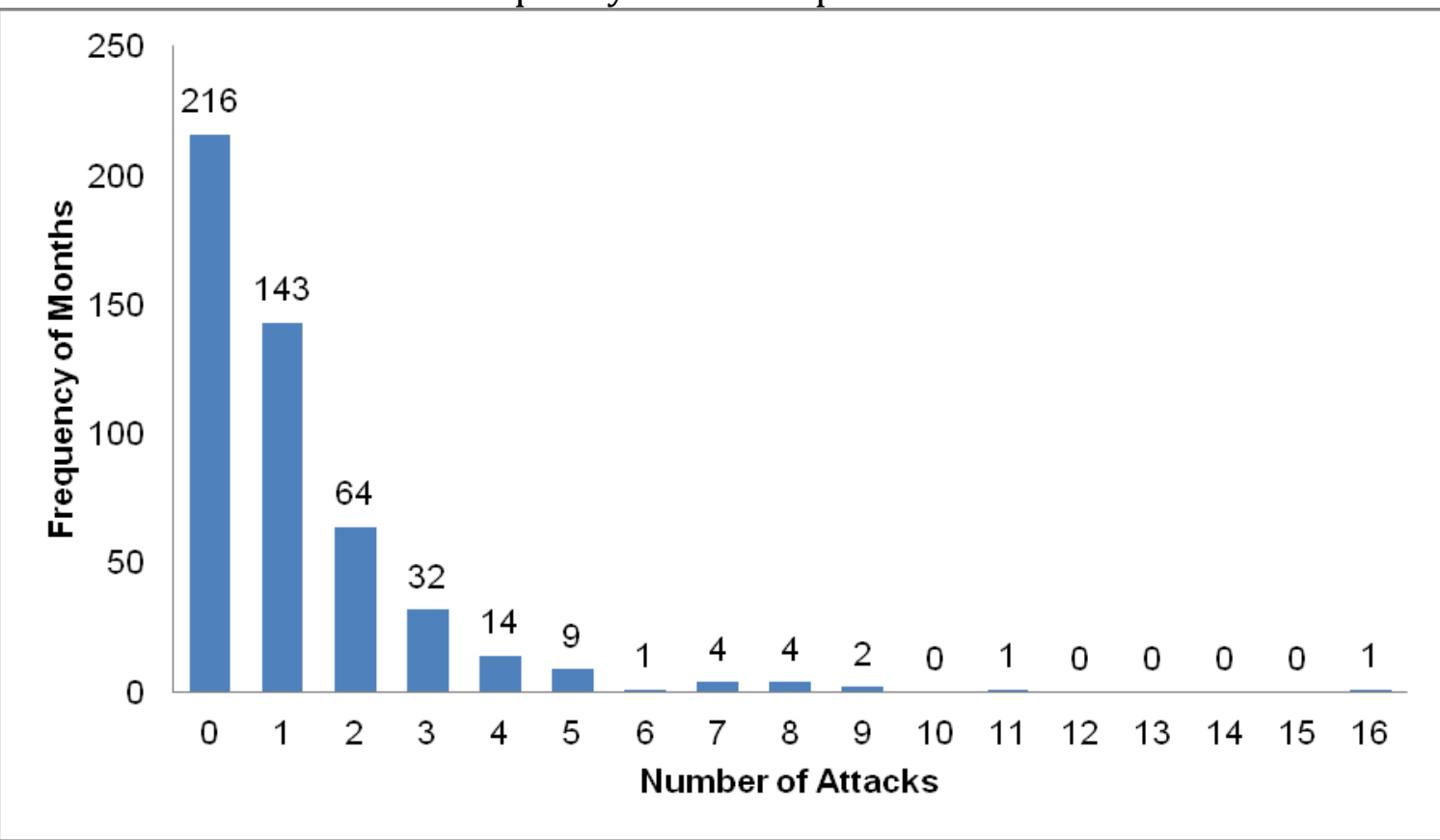


Figure 2a

Attacks per Year

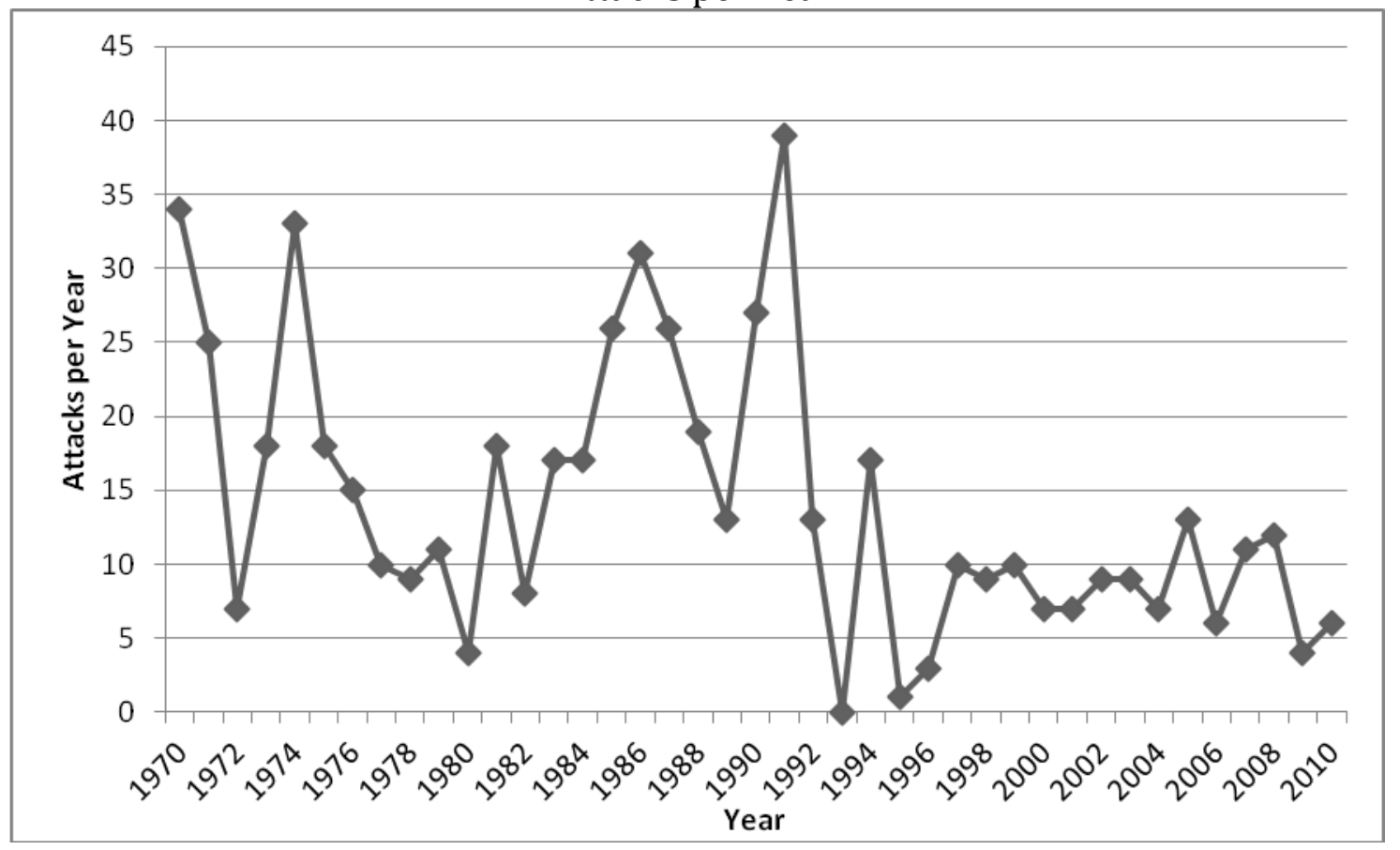

Figure 3

Frequency of Domestic Attacks per Month

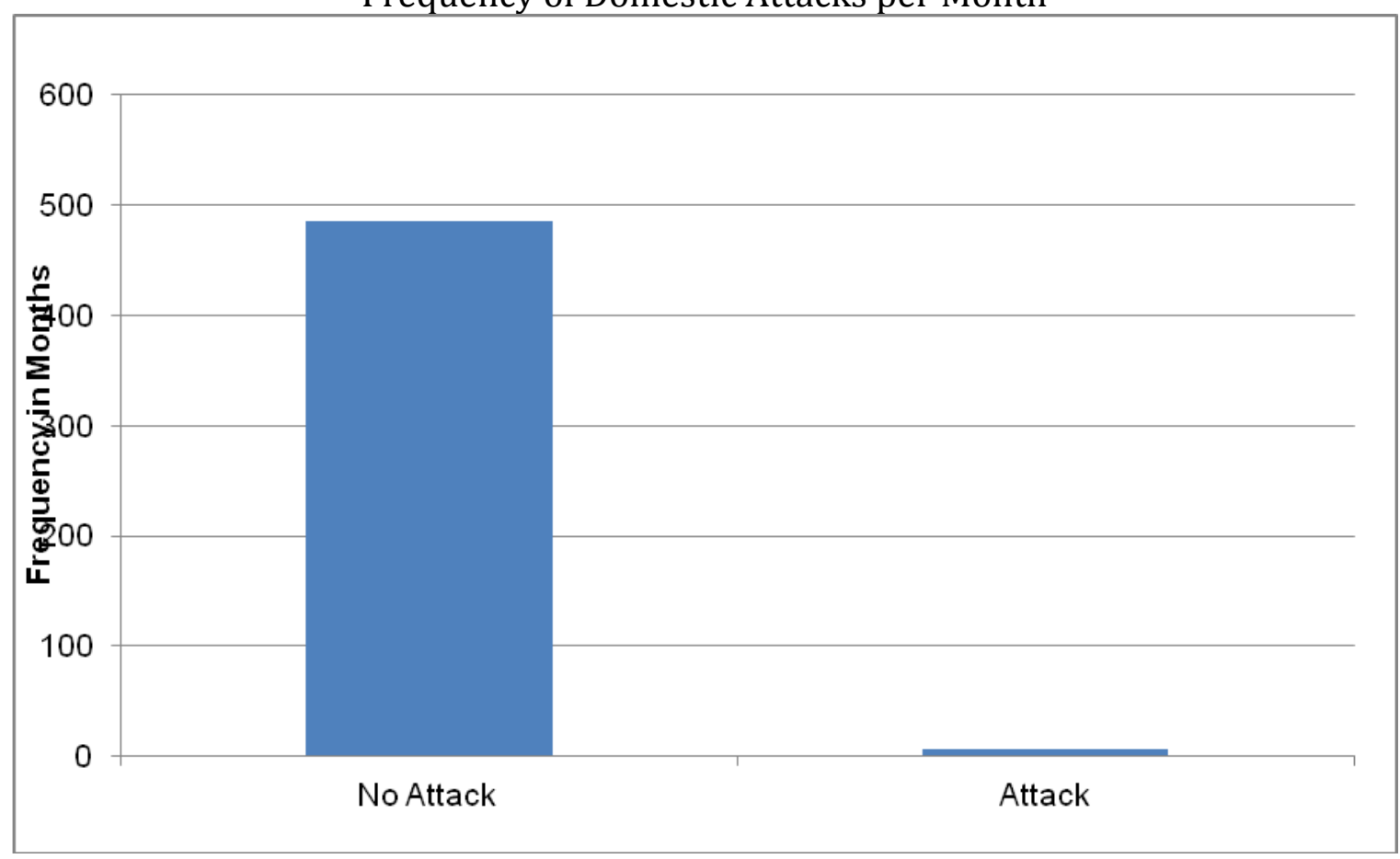


Figure 4

Frequency of Attack in the Middle East per Month

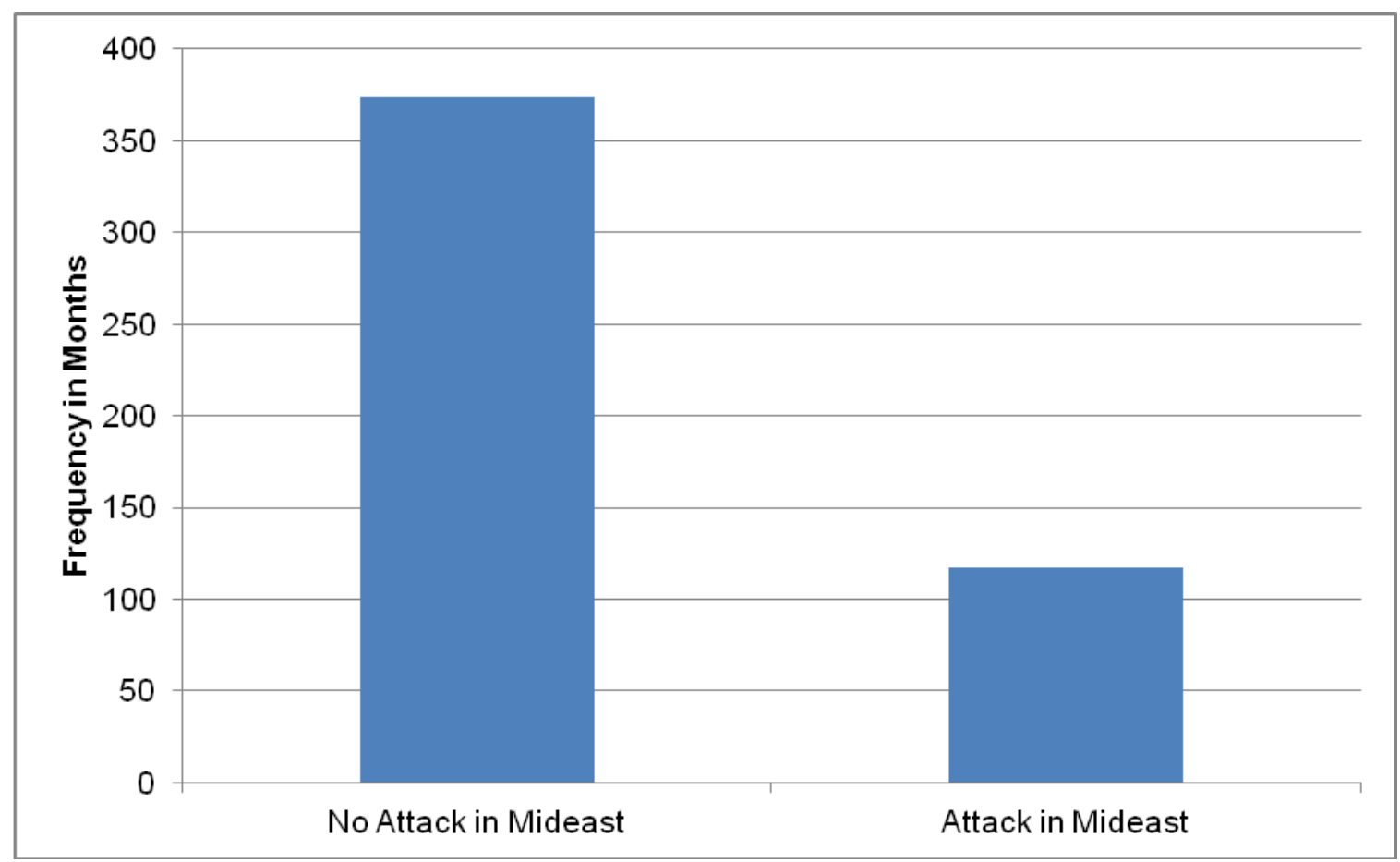

Figure 5

Frequency of Lethal Attacks per Month

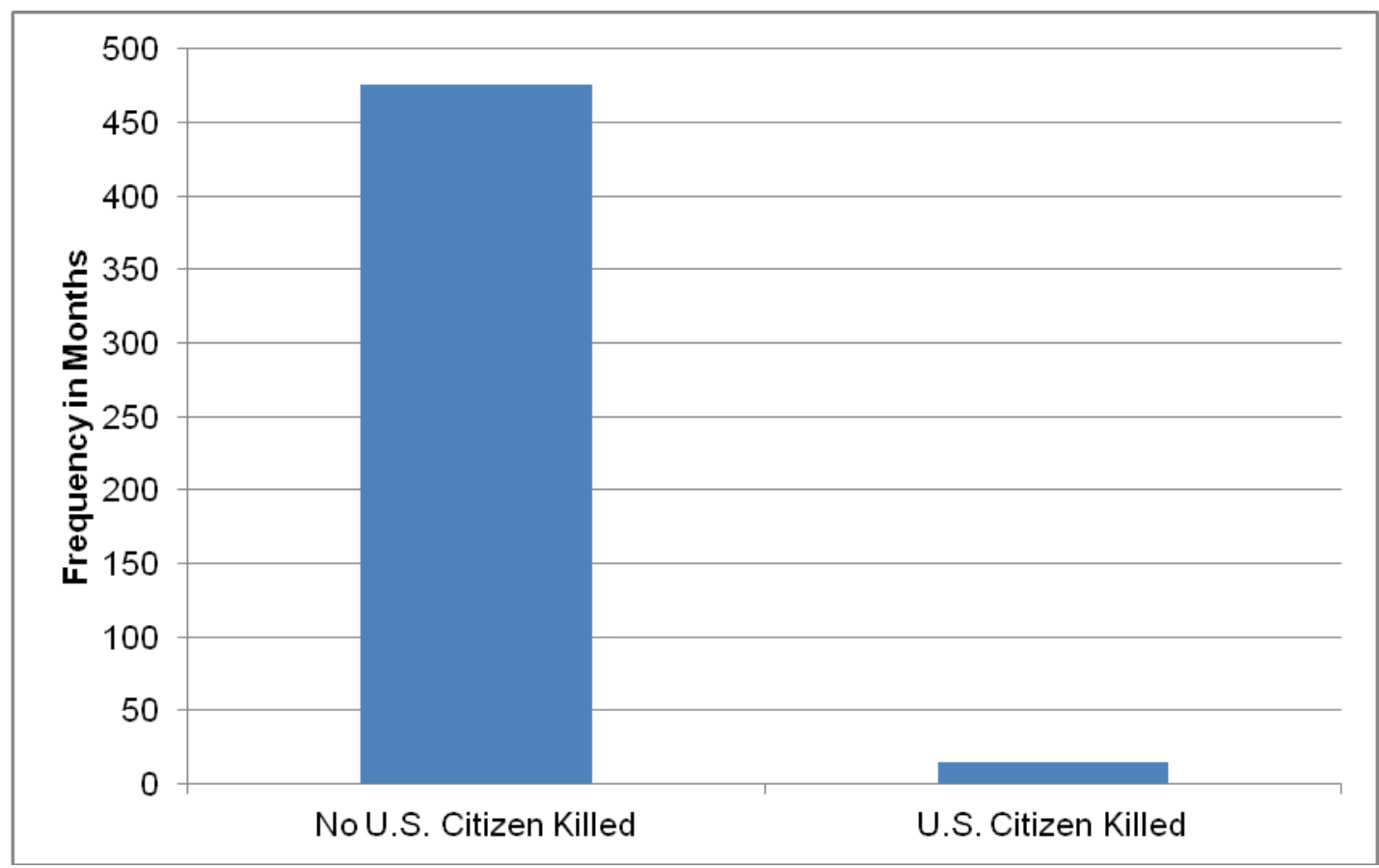




\section{APPENDIX 2}

Table 1: Descriptive Statistics

\begin{tabular}{|c|c|c|c|c|}
\hline & Variable & Description & $\begin{array}{c}\text { Sample } \\
\text { Statistics } \\
\end{array}$ & $\begin{array}{c}\text { Sample Statistic } \\
(1970-2000)\end{array}$ \\
\hline Dependent & $\begin{array}{l}\text { Presidential } \\
\text { Approval }\end{array}$ & $\begin{array}{l}\text { Presidential approval rate, } \\
\text { measured in percentage points }\end{array}$ & $\begin{array}{c}51.601 \\
(12.067)\end{array}$ & $\begin{array}{c}52.07 \\
(10.97)\end{array}$ \\
\hline Independent & Terrorist Attacks & $\begin{array}{c}\text { Terrorist attack, measured by } \\
\text { number of terrorist attacks in a } \\
\text { month }\end{array}$ & $\begin{array}{c}0.562 \\
(0.497)\end{array}$ & \\
\hline Independent & Attacks per month & $\begin{array}{l}\text { Total terrorist attacks per } \\
\text { month, measured in number of } \\
\text { attacks }\end{array}$ & $\begin{array}{c}1.179 \\
(1.738)\end{array}$ & $\begin{array}{c}1.33 \\
(1.912)\end{array}$ \\
\hline Independent & Total U.S. Killed & $\begin{array}{c}\text { Total number of U.S. citizens } \\
\text { killed in attack, measured in } \\
\text { number of U.S. deaths }\end{array}$ & $\begin{array}{c}7.36 \\
(142.82)\end{array}$ & \\
\hline Independent & $\begin{array}{c}\text { Total Killed in } \\
\text { Bargaining Attack }\end{array}$ & $\begin{array}{l}\text { Total number of U.S. killed in } \\
\text { bargaining style attack }\end{array}$ & $\begin{array}{c}6.527 \\
(142.43)\end{array}$ & \\
\hline Independent & $\begin{array}{l}\text { Total Killed in } \\
\text { Bombing Attack }\end{array}$ & $\begin{array}{c}\text { Total number of U.S. killed in } \\
\text { bombing attack }\end{array}$ & $\begin{array}{c}.7128 \\
(10.999)\end{array}$ & \\
\hline Independent & $\begin{array}{l}\text { Total Killed in an } \\
\text { Infrastructure }\end{array}$ & $\begin{array}{l}\text { Total number of U.S. killed in } \\
\text { infrastructure attack }\end{array}$ & $\begin{array}{l}.0041 \\
(.0638)\end{array}$ & \\
\hline Independent & Domestic Attack & $\begin{array}{l}\text { Was the attack perpetrated on } \\
\text { U.S. soil, measured by location }\end{array}$ & $\begin{array}{c}.0122 \\
(.10998)\end{array}$ & \\
\hline Independent & Middle East Attack & $\begin{array}{l}\text { Did attack happen in Middle } \\
\text { East region, measured by the } \\
\text { location of attack }\end{array}$ & $\begin{array}{l}.2383 \\
(.4265)\end{array}$ & \\
\hline Independent & $\begin{array}{l}\text { GOP*Number of } \\
\text { U.S. Killed }\end{array}$ & $\begin{array}{l}\text { Interaction term between GOP } \\
\text { and number of U.S. killed in an } \\
\text { attack }\end{array}$ & $\begin{array}{c}7.189 \\
(142.818)\end{array}$ & \\
\hline Independent & GOP*Domestic & $\begin{array}{l}\text { Interaction term between GOP } \\
\text { and if attack was domestic }\end{array}$ & $\begin{array}{l}.0061 \\
(.078)\end{array}$ & $\begin{array}{c}.0054 \\
(.0732)\end{array}$ \\
\hline Independent & U.S. in Wartime & $\begin{array}{c}\text { Was U.S. at war during time of } \\
\text { attack }\end{array}$ & $\begin{array}{l}.3177 \\
(.466)\end{array}$ & $\begin{array}{l}.124 \\
(.3300)\end{array}$ \\
\hline Independent & $\begin{array}{l}\text { Unemployment } \\
\text { Rate }\end{array}$ & $\begin{array}{l}\text { National unemployment rate, } \\
\text { measured in percentage points }\end{array}$ & $\begin{array}{c}6.3 \\
(1.527)\end{array}$ & $\begin{array}{c}6.35 \\
(1.434)\end{array}$ \\
\hline Independent & Honeymoon & $\begin{array}{c}\text { Popularity boost for first } 12 \\
\text { months, the } 1 \text { st month }=12 \text {, and } \\
\text { so on until the } 12^{\text {th }} \text { month }=1, \& \\
0 \text { for months thereafter }\end{array}$ & $\begin{array}{c}.169 \\
(.3752)\end{array}$ & $\begin{array}{l}.1586 \\
(.366)\end{array}$ \\
\hline Independent & GOP & $\begin{array}{l}\text { Dummy Variable. Equal to } 1 \text { if } \\
\text { president was a Republican }\end{array}$ & $\begin{array}{l}.6599 \\
(.4742)\end{array}$ & \\
\hline Independent & $\begin{array}{l}\text { Log of Time in } \\
\text { Office }\end{array}$ & $\begin{array}{l}\text { Log of the amount of time } \\
\text { president has been in office, } \\
\text { measured in number of days }\end{array}$ & $\begin{array}{c}6.697 \\
(1.060)\end{array}$ & $\begin{array}{c}6.70 \\
(1.025)\end{array}$ \\
\hline Independent & Scandal & $\begin{array}{c}\text { Dummy Variable. Equals } 1 \text { for } \\
\text { the period 04/1973-07/1974, } \\
\text { 12/1986-12/1988, 01/1998- } \\
08 / 1998\end{array}$ & $\begin{array}{l}.1039 \\
(.3054)\end{array}$ & $\begin{array}{l}.1370 \\
(.3444)\end{array}$ \\
\hline Independent & 9/11 Indicator & $\begin{array}{c}\text { Dummy Variable. Equal to } 1 \text { for } \\
5 \text { months after } 9 / 11 \text { attack }\end{array}$ & $\begin{array}{l}.0081 \\
(.09)\end{array}$ & \\
\hline \multicolumn{3}{|c|}{ Number of observations } & 491 & 371 \\
\hline
\end{tabular}

Notes: Mean and standard deviation (in parenthesis) reported above. The mean for number of attacks per month post 9/11 was .718 . 
Table 2: Regression Output

\begin{tabular}{|c|c|c|c|c|c|c|c|}
\hline Model & $\begin{array}{l}\text { Effect of } \\
\text { Number of } \\
\text { Attacks per } \\
\text { Month } \\
\text { (1) }\end{array}$ & $\begin{array}{c}\text { Effect of } \\
\text { Number of } \\
\text { Attacks per } \\
\text { Month } \\
1970-2000 \\
\text { (1a) }\end{array}$ & $\begin{array}{l}\text { Effect of } \\
\text { Location } \\
\text { (2) }\end{array}$ & $\begin{array}{l}\text { Effect of } \\
\text { Number of } \\
\text { U.S. Killed } \\
\text { (3) }\end{array}$ & $\begin{array}{c}\text { Effect of } \\
\text { Political } \\
\text { Party with } \\
\text { Number of } \\
\text { U.S. Killed } \\
\text { (4) }\end{array}$ & $\begin{array}{c}\text { Effect of } \\
\text { Political } \\
\text { Party with } \\
\text { Domestic } \\
\text { Attack } \\
\text { (5) }\end{array}$ & $\begin{array}{l}\text { Effect of } \\
\text { Political } \\
\text { Party with } \\
\text { Domestic } \\
\text { Attack } \\
\text { (5a) }\end{array}$ \\
\hline $\begin{array}{c}\text { Dependent } \\
\text { Variable }\end{array}$ & $\begin{array}{c}\text { Presidential } \\
\text { Approval }\end{array}$ & $\begin{array}{c}\text { Presidential } \\
\text { Approval }\end{array}$ & $\begin{array}{c}\text { Presidential } \\
\text { Approval } \\
\end{array}$ & $\begin{array}{c}\text { Presidential } \\
\text { Approval } \\
\end{array}$ & $\begin{array}{c}\text { Presidential } \\
\text { Approval } \\
\end{array}$ & $\begin{array}{c}\text { Presidential } \\
\text { Approval } \\
\end{array}$ & $\begin{array}{c}\text { Presidential } \\
\text { Approval } \\
\end{array}$ \\
\hline $\begin{array}{c}\text { Log of Days in } \\
\text { Office }\end{array}$ & $\begin{array}{c}-2.66^{* * *} \\
(.6898)\end{array}$ & $\begin{array}{c}-3.49^{* * *} \\
(.794)\end{array}$ & $\begin{array}{c}-2.859^{* * *} \\
(.807)\end{array}$ & $\begin{array}{c}-2.94^{* * *} \\
(.844)\end{array}$ & $\begin{array}{c}-2.74^{* * * *} \\
(.763)\end{array}$ & $\begin{array}{c}-2.80^{* * * *} \\
(.803)\end{array}$ & $\begin{array}{c}-4.21^{* * *} \\
(.953)\end{array}$ \\
\hline Honeymoon & $\begin{array}{c}4.65^{*} \\
(2.562)\end{array}$ & $\begin{array}{c}3.72 \\
(2.66)\end{array}$ & $\begin{array}{l}7.35^{* *} \\
(3.07)\end{array}$ & $\begin{array}{c}7.598^{* *} \\
(3.14)\end{array}$ & $\begin{array}{l}7.96^{* *} \\
(2.90)\end{array}$ & $\begin{array}{l}8.08^{* * *} \\
(3.06)\end{array}$ & $\begin{array}{c}7.808^{* *} \\
(3.27)\end{array}$ \\
\hline $\begin{array}{l}\text { Number of } \\
\text { Attacks per } \\
\text { Month }\end{array}$ & $\begin{array}{l}.362^{* *} \\
(.1696)\end{array}$ & $\begin{array}{l}.383^{* *} \\
(1.80)\end{array}$ & & & & & \\
\hline Domestic & & & $\begin{array}{l}4.48^{* *} \\
(1.86)\end{array}$ & & & $\begin{array}{c}-.897 \\
(2.599)\end{array}$ & $\begin{array}{l}-.703 \\
(2.96)\end{array}$ \\
\hline Domestic $\mathrm{t}_{\mathrm{t}-6}$ & & & $\begin{array}{c}.819 \\
(1.72)\end{array}$ & & & & \\
\hline Middle East & & & $\begin{array}{l}-.390 \\
(.538)\end{array}$ & & & & \\
\hline Middle Eastt- 6 & & & $\begin{array}{l}-1.36^{* *} \\
(.5401)\end{array}$ & & & & \\
\hline $\begin{array}{c}\text { Number Killed } \\
\text { US }\end{array}$ & & & & $\begin{array}{c}.443 \\
(.3598)\end{array}$ & $\begin{array}{c}.0104^{* * *} \\
(.0015)\end{array}$ & & \\
\hline $\begin{array}{l}\text { Number Killed } \\
\text { Bargaining } \\
\text { Attack }\end{array}$ & & & & $\begin{array}{c}-.443 \\
(.3598)\end{array}$ & & & \\
\hline $\begin{array}{l}\text { Number Killed } \\
\text { Bombing Attack }\end{array}$ & & & & $\begin{array}{c}-.405 \\
(.3602)\end{array}$ & & & \\
\hline $\begin{array}{l}\text { Number Killed } \\
\text { Infrastructure } \\
\text { Attack }\end{array}$ & & & & $\begin{array}{l}-4.52 \\
(3.57)\end{array}$ & & & \\
\hline GOP & & & & & $\begin{array}{l}-4.49 \\
(5.87) \\
\end{array}$ & $\begin{array}{l}-2.96 \\
(6.32)\end{array}$ & $\begin{array}{c}-26.95^{* * *} \\
(8.14) \\
\end{array}$ \\
\hline $\begin{array}{c}\text { GOP*Number } \\
\text { U.S. Killed }\end{array}$ & & & & & $\begin{array}{c}.0066^{* * *} \\
(.0016) \\
\end{array}$ & & \\
\hline GOP*Domestic & & & & & & $\begin{array}{c}10.73^{* * *} \\
(3.644)\end{array}$ & $\begin{array}{l}2.207 \\
(4.23)\end{array}$ \\
\hline Wartime $_{t-1}$ & $\begin{array}{l}9.22^{* * *} \\
(2.04)\end{array}$ & $\begin{array}{l}9.61^{* * *} \\
(2.22)\end{array}$ & $\begin{array}{l}5.88^{* *} \\
(2.38)\end{array}$ & $\begin{array}{l}5.46^{* *} \\
(2.61)\end{array}$ & $\begin{array}{c}8.45^{* * *} \\
(2.43)\end{array}$ & $\begin{array}{l}5.65^{* *} \\
(2.36)\end{array}$ & $\begin{array}{c}2.16 \\
(2.87)\end{array}$ \\
\hline Unemployment $_{\mathrm{t} 1}$ & $\begin{array}{l}-2.19^{* *} \\
(.793) \\
\end{array}$ & $\begin{array}{c}-3.33^{* * *} \\
(.962) \\
\end{array}$ & $\begin{array}{l}-1.55^{*} \\
(.928) \\
\end{array}$ & $\begin{array}{c}.881 \\
(.998) \\
\end{array}$ & $\begin{array}{c}-1.72^{* *} \\
(.873) \\
\end{array}$ & $\begin{array}{l}-1.37 \\
(.914) \\
\end{array}$ & $\begin{array}{l}2.46^{* *} \\
(1.20) \\
\end{array}$ \\
\hline Scandal & $\begin{array}{c}-9.73^{* * *} \\
(2.11) \\
\end{array}$ & $\begin{array}{l}-9.67^{* * *} \\
(2.16) \\
\end{array}$ & $\begin{array}{l}-6.90^{* *} \\
(2.35) \\
\end{array}$ & $\begin{array}{c}-6.496^{* *} \\
(2.36) \\
\end{array}$ & $\begin{array}{l}-6.98^{* *} \\
(2.22) \\
\end{array}$ & $\begin{array}{c}-6.64^{* * *} \\
(2.31) \\
\end{array}$ & $\begin{array}{c}-5.64^{* *} \\
(2.42) \\
\end{array}$ \\
\hline 9/11 Indicator & $\begin{array}{c}20.53^{* * *} \\
(3.38)\end{array}$ & & $\begin{array}{l}8.73^{* *} \\
(3.87)\end{array}$ & $\begin{array}{c}4.41 \\
(4.76)\end{array}$ & $\begin{array}{c}10.07^{* *} \\
(4.57)\end{array}$ & $\begin{array}{c}10.49^{* * *} \\
(3.90)\end{array}$ & \\
\hline Month Dummy & Yes & Yes & Yes & Yes & Yes & Yes & Yes \\
\hline Year Dummy & Yes & Yes & Yes & Yes & Yes & Yes & Yes \\
\hline R-Squared & .7826 & .7289 & .4293 & .3870 & .4915 & .4257 & .2476 \\
\hline Observations & 491 & 371 & 491 & 491 & 491 & 491 & 371 \\
\hline
\end{tabular}


Table 3: Serial Correlation Correction

\begin{tabular}{|c|c|c|}
\hline Model & Original DW Statistic & Transformed DW Statistic \\
\hline$(1)$ & 1.153 & 2.089 \\
\hline$(1 \mathrm{a})$ & 1.0613 & 2.119 \\
\hline$(2)$ & 1.158 & 2.067 \\
\hline$(3)$ & 1.216 & 2.097 \\
\hline$(4)$ & 1.106 & 2.077 \\
\hline$(5)$ & 1.14 & 2.08 \\
\hline$(5 \mathrm{a})$ & 1.039 & 2.116 \\
\hline
\end{tabular}

